\title{
PSATHYRELLA EUTHYGRAMMA (AGARICALES, BASIDIOMYCOTA), A NEW RECORD FROM BRAZIL
}

\author{
Felipe Wartchow ${ }^{1} \&$ Ana R. P. Gomes ${ }^{2}$
}

\begin{abstract}
${ }^{1}$ Universidade Federal da Paraíba, Departamento de Sistemática e Ecologia, Pós-Graduação em Biologia de Fungos, CEP 58051-970, João Pessoa, PB, Brazil; fwartchow@yahoo.com.br (author for correspondence).

${ }^{2}$ Universidade Federal de Pernambuco, Departamento de Micologia, Av. Nelson Chaves s/n, 50760-420, Recife, PE, Brazil.
\end{abstract}

\begin{abstract}
Wartchow, F. \& A. R. P. Gomes. 2019. Psathyrella euthygramma (Agaricales, Basidiomycota), a new record from Brazil. Darwiniana, nueva serie 7(1): 187-190.

Psathyrella euthygramma is reported for the first time from Brazil, growing on rotting wood in the Atlantic Forest. The diagnostic features are the small basidiomes with stipe bearing a fugacious annulus and densely strigose base, the small basidiospores bearing germ pore and cystidia thin to slightly thick walled.
\end{abstract}

Keywords. Agaricomycetes; Atlantic Forest; Neotropic; Psathyrellaceae.

Resumen. Wartchow, F. \& A. R. P. Gomes. 2019. Psathyrella euthygramma (Agaricales, Basidiomycota), nuevo registro para Brasil. Darwiniana, nueva serie 7(1): 187-190.

Psathyrella euthygramma es citada por primera vez para Brasil, creciendo sobre madera en descomposición en la Selva Atlántica. Los caracteres diagnósticos son los basidiomas pequeños, el estipe con un anillo fugaz y la base densamente estrigosa, las basidiosporas pequeñas, con poro germinativo y cistídios de paredes finas a ligeramente engrosadas.

Palabras clave. Agaricomycetes; Neotrópico; Psathyrellaceae; Selva Atlántica.

\section{INTRODUCTION}

Psathyrella (Fr.) Quél. is a huge genus comprising above 600 species with a worldwide distribution (Kirk et al., 2008). However, recent molecular studies refer this genus as polyphyletic on which at lest 11 distinct clades among the genus were observed (Padamsee et al., 2008; Örstadius et al., 2015).

Although the high diversity, this genus is poorly known in Brazil and references about this genus is scarce and fragmented. Putzke (1994), the first to account total agarics richness in Brazil, reports only 14 taxa until that date. Many of these taxa were already reported by Rick (1961) from the State of Rio Grande do Sul. Singer $(1961,1989)$ reported more species from Amazonas, and Bononi et al. (1981, 1984), Grandi et al. (1984) and Pegler (1997) from São Paulo. Later works recorded more species from the states of Rio Grande do Sul (Cortez \& Coelho 2005), Mato Grosso do Sul (Bononi et al. 2008), and Minas Gerais (Rosa \& Capelari 2009). Thus, here we report $P$. euthygramma for the first time from the State of Pernambuco, Brazil.

\section{MATERIAL AND METHODS}

The new species was collected in municipality of Igarassu, near of Usina São José (Mata dos Macacos) located in the North coast of State of 
Pernambuco $\left(7^{\circ} 40^{\prime} 7^{\circ} 55^{\prime} \mathrm{S}, \quad 34^{\circ} 54^{\prime} \quad 35^{\circ} 05^{\prime} \mathrm{W}\right)$, where Atlantic Forest is dominant, defined as Lowland Seasonal Semideciduous Forest (De Luna et al., 2016). Microscopic observations were made from material mounted in $3 \% \mathrm{KOH}$, Congo red solution and Melzer's reagent. Measurements and statistics are based in 30 spores. Abbreviations include av. = average size of basidiospores measured, $\mathrm{Q}=$ the length: width ratio range as determined from all basidiospores measured, Qm $=$ the $\mathrm{Q}$ value averaged from all basidiospores measured. Herbarium code follows Thiers (continuously updated, consulted 2019).

\section{TAXONOMY}

Psathyrella euthygramma (Berkeley \& M.A. Curtis) Dennis, Kew Bull. 15: 127. 1961.

Agaricus euthugrammus Berk. \& M.A. Curtis, J. Linn. Soc. 10: 290. 1868.

Material examined. Brazil, Pernambuco, Igarassu, Usina São José, Mata dos Macacos, 20VI-2005, F. Wartchow 12/2005 (JPB 63209).

BASidiomata, small, fragile, densely gregarious. Pileus 12-24 mm in diam., plane convex, brown (M\&P "Stag"), sulcate-striate from the centre, surface glabrous, smooth, dry. LAMELLAE adnexed, brown, thin, subclose, with frequent lamellulae. STIPE 18-28 × 2-3 mm, central, cylindrical, white to pale grayish, glabrous, except at base that is densely strigose; annulus gracile, fragile, membranous near to pileus, white, soon evanescent. Context very thin, fleshy.

BASIDIOSPORES 5-6(-6.5) $\times$ 2.5-3.6 $\mu \mathrm{m}$, av. 5.47 $\times 2.96 \mu \mathrm{m} ; \mathrm{Q}=(1.42-)$ 1.66-2.40(-2.60), $\mathbf{Q m}=$ 1.89 , elongate-ellipsoid to cylindrical, pale brown in $\mathrm{KOH} 3 \%$, hilar appendix very indistinct, truncate with a broad germ pore, wall slightly thick. BAsIDIA $12-15 \times 5-6 \mu \mathrm{m}$, clavate with two or four sterigmata. Pleurocystidia $30-42 \times 10-13 \mu \mathrm{m}$, lageniform to somewhat fusoid, hyaline, thin to slightly thick walled (less than $2 \mu \mathrm{m}$ thick), with incrusted apex, very common. CheILOCystidia 20-25(-32) × 7.5$12 \mu \mathrm{m}$, ranging from piriform, inflated clavate to fusoid lageniform and utriform, hyaline to very pale grayish brown, with walls slightly thickened (thinner than pleurocystidia). PILEIPELLIS a stratified epithelium with cells $30-47 \times 22-35 \mu \mathrm{m}$, commonly subglobose, pale grey to almost colorless pigment. STRIGOSE BASE OF THE STIPE made of agglomeration of hyphae with parallel orientation presenting clamp connections in all septa.

Known distribution. Cuba (Berkeley \& Curtis 1968), Venezuela (Dennis 1961) and now State of Pernambuco, Brazil.

Habitat. gregarious on rotten wood in fragment of tropical rain forest.

\section{DISCUSSION}

Psathyrella euthygramma is characterized by its caespitose habit, small and fragile basidiomata, stipe bearing an annulate zone, strigose base bearing thin walled but sometimes thickening to $1.5 \mu \mathrm{m}$ thick hyphae, and small and narrow basidiospores 5-6 (-6.5) × 2.5-3.6 $\mu \mathrm{m}$.

Here we consider the species described from Cuba as Agaricus euthugrammus Berk. \& M.A. Curtis the same entity. It possesses smaller pileus reaching $8 \mathrm{~mm}$ in diam. and a filiform stipe that is distinctly strigose at base (Berkeley \& Curtis, 1868). Microscopically, Kits van Waveren (1995) found shorter basidiospores 4.5-5 × 3-3.5 $\mu \mathrm{m}$ without germ pore and several thin-walled pleurocystidia and mentioned that Smith's (1972) basidiospores drawings were probably erroneously depicted. Dennis (1961) also did not refer to germ pore in the Venezuelan material of $P$. euthygramma, but he frequently did not cite this feature for almost any species cited by him. Actually, we strongly conclude that our specimens belong to $P$. euthygramma. Although Kits van Waveren (1995) reported the absence of germ pore in the basidiospores of the holotype, is important to mention that the type specimens were described with much smaller pileus diameter $(8 \mathrm{~mm})$. Probably the lack of germ pore is due age of the basidiomata, on which only in more mature ones, as occur in Brazilian collection, the germ pore is evident. We consider our collection as mature basing in the size of the basidiomata. 

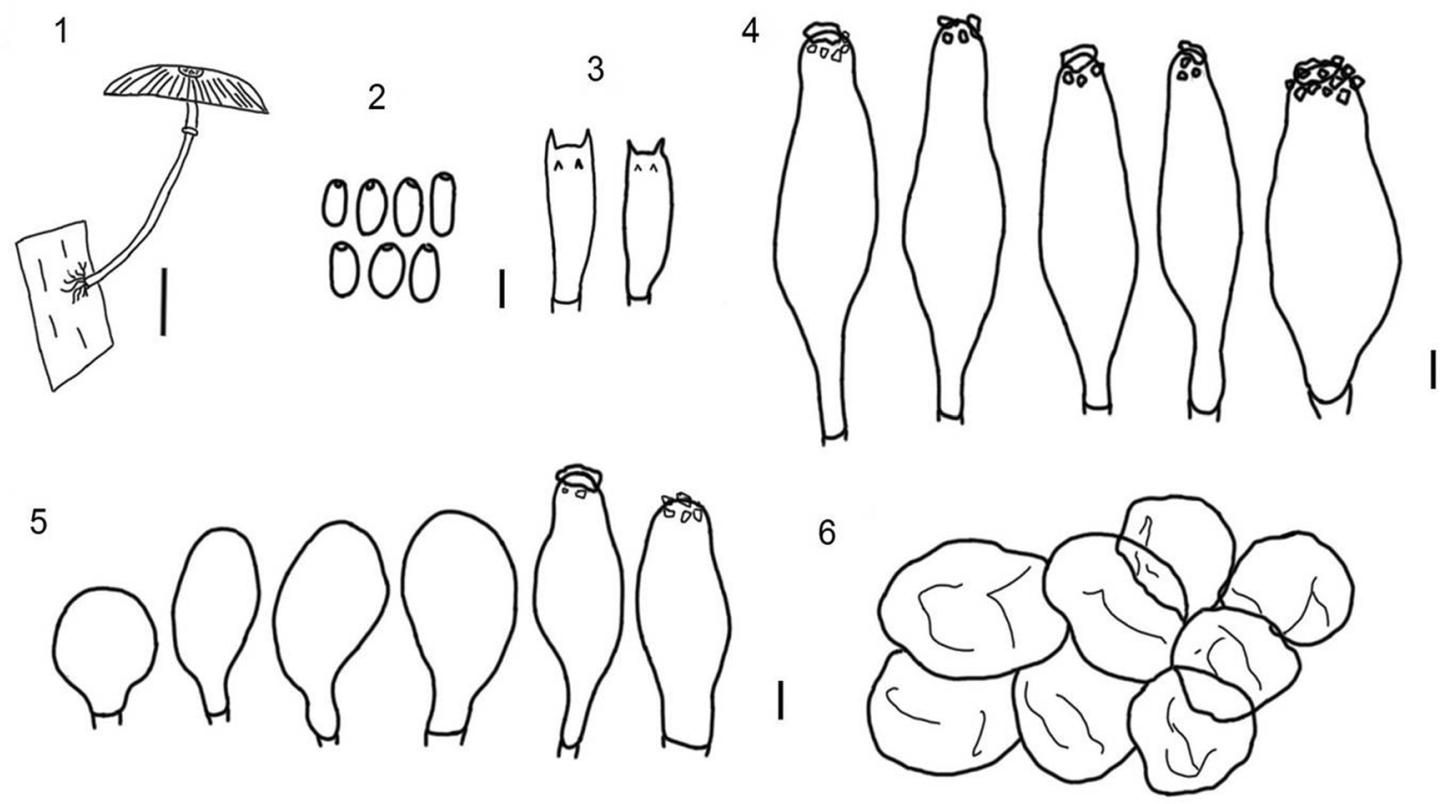

Figs. 1-6. Psathyrella euthygramma. 1, Basidioma. Bars $=10 \mathrm{~mm}$. 2, Basidiospores. 3, Basidia. 4, Pleurocystidia. 5, Cheilocystidia. 6, Pileipellis. Bars $=10 \mu \mathrm{m}$.

The European P. pygmaea (Bull.: Fr.) Singer, also can be discussed here, but it is rather distinct from $P$. euthygramma if observing critical macroscopic features: the basionym of P. pygmaea, Agaricus pygmaeus Bull., was illustrated without any trace of strigose stipe base nor annulus (Bulliard, 1790). Later, Fries (1821) sanctioned A. pygmaeus and described it as having fistulous stipe with pubescent base, not exactly strigose base as observed in $P$. euthygramma. Saccardo (1888) reported 'Naucoria (Agaricus) pygmaeus' as having fistulous and glabrous stipe. Other authors also did not report the strigose stipe base on collections of $P$. pygmaea from Europe (Kits van Waveren, 1985; Breitenbach \& Kränzlin, 1995) and East Africa (Pegler, 1977). Basing in the more recent description of $P$. pygmaea from Europe, the basidiospores are distinctly more voluminous 6-7 × 3.5-4 $\mu \mathrm{m}$, the stipe has not any trace of annular zone and its base is not strigose (Vasutová, 2008). Summarizing, P. pygmaea differs from $P$. euthygramma in the lack of annular zone in the stipe, pubescent instead strigose stipe base and the larger basidiospores.

\section{ACKNOWLEDGEMENTS}

The authors thank CNPq (PROTAX/CNPQ/ MCT Proc. 563969/05-9; DTI Proc. 390261/05-0 'Produtividade em Pesquisa' Proc. 307922/2014-6 and Proc. 307947/2017-3), and FACEPE ('Bolsa de Fixação de Pesquisador' Proc. 0100-2.03/09).

\section{BIBLIOGRAPHY}

Berkeley, M. J. \& M. A. Curtis. 1868. Fungi Cubenses (Hymenomycetes). Journal of the Linnean Society, Botany 10: 280-392. DOI: 10.1111/j.1095-8339.1868.tb00529.x

Bononi, V. L. R.; S. F. B. Trufem \& R. A. P. Grandi. 1981. Fungos macroscópicos depositados no Herbário do Instituto de Botânica de São Paulo. Rickia 9: 37-53.

Bononi, V. L. R.; E. S. F. Mucci, N. K. S. Yokomizo \& G. Guzmán. 1984. Agaricales (Basidiomycetes) do Parque Estadual de Campos do Jordão, SP, Brasil. Rickia 11: 85-89.

Bononi, V. L. R.; A. K. M. Oliveira, J. R. Quevedo \& A. M. Gugliotta. 2008. Fungos macroscópicos do Pantanal do Rio Negro, Mato Grosso do Sul, Brasil. Hoehnea 35: 489-511.

Breitenbach, J. \& Kranzlin F. 1995. Fungi from Switzerland. Agarics. $2^{\text {nd }}$ part. IV. Lucerne, Mykologia Lucerne.

Bulliard, P. 1790. Herbier de la France. Paris. 
Cortez, V. G. \& G. Coelho. 2005. Additions to the mycobiota (Agaricales, Basidiomycetes) of Rio Grande do Sul, Brazil. Iheringia, Série Botânica 60: 69-75.

Dennis, R. W. G. 1961. Fungi venezuelani: IV. Agaricales. Kew Bulletin 15: 67-156. DOI: 10.2307/4115784

De Luna, N. K. M.; E. Pessoa \& M. Alves. 2016. Flora da Usina São José, Igarassu, Pernambuco: Zingiberales. Rodriguésia 67: 261-273. DOI: 10.1590/2175-7860201667114

Fries, E. M. 1821. Systema Mycologicum. I. Lunde, Lund \& Greifswald, Ex Officina Berlingiana.

Grandi, R. A. P.; G. Guzmán \& V. L. R. Bononi. 1984. Adições às Agaricales (Basidiomycetes) do Parque Estadual das Fontes do Ipiranga, São Paulo, Brasil. Rickia 11: 27-33.

Kirk, P. M.; P. F. Cannon, D. W. Minter \& J. A. Stalpers. 2008. Ainsworth \& Bisby's Dictionary of the Fungi. $10^{\text {th }}$ Ed. Wallingford, CAB International.

Kits van Waveren, E. 1985. The Ducth, French and British species of Psathyrella. Persoonia Supplement 2: 1-300.

Kits van Waveren, E. 1995. The Berkeley \& Broome species of Psathyrella in the Kew Herbarium. Kew Bulletin 50: 307325.

Örstadius, L.; M. Rygberg \& E. Larsson. 2015. Molecular phylogenetics and taxonomy in Psathyrellaceae (Agaricales) with focus on psathyrelloid species: introduction of three new genera and 18 new species. Mycological Progres 14: 25. DOI: $10.1007 / \mathrm{s} 11557-015-1047-\mathrm{x}$

Padamsee, M.; P. B. Matheny, B. T. M., Dentinger \& D. J. McLaughlin. 2008. The mushroom family Psathyrellaceae: evidence for large-scale polyphyly of the genus Psathyrella.
Molecular Phylogenetics and Evolution 46: 415-429. DOI: 10.1016/j.ympev.2007.11.004

Pegler, D. N. 1977. A preliminary agaric flora of East Africa. Kew Bulletin Additional Series 6: 1-615.

Pegler, D. N. 1997. The Agarics of São Paulo, Brazil. Royal Botanic Garden, Kew.

Putzke, J. 1994. Lista dos fungos Agaricales (Hymenomycetes, Basidiomycotina) referidos para o Brasil. Caderno de Pesquisa, Série Botânica 6: 1-189.

Rick, J. 1961. Basidiomycetes Eubasidii in Rio Grande do Sul Brasília 5. Iheringia, Série Botânica 8: 296-450.

Rosa, L. H. \& M. Capelari. 2009. Agaricales fungi from Atlantic rain Forest fragments in Minas Gerais, Brazil. Brazilian Journal of Microbiology 40: 846-851. DOI: 10.1590/S151783822009000400015

Saccardo, P. A. 1888. Sylloge Fungorum V. Patavii.

Singer, R. 1961. Fungi of Northern Brazil. Publicação do Instituto de Micologia da Universidade do Recife 304: 1-26.

Singer, R. 1989. New taxa and new combinations in the Agaricales (Diagnoses Fungorum Novorum Agaricalium IV). Fieldiana Botany 21: 1-133.

Smith, A. H. 1972. The North American species of Psathyrella. Memoirs of the New York Botanic Garden 24: 1-633.

Thiers, B. [continuously updated, consulted 2019]. Index Herbariorum: a global directory of public herbaria and associated staff. New York Botanical Garden's Virtual Herbarium. Available from: htttp://sweetgum.nybg.org/ih/

Vašutová, M. 2008. Taxonomic studies on Psathyrella sect. Spadiceae. Czech Mycology 60: 137-171. 